\title{
PROFILE OF LINGUISTIC AND COGNITIVE DEFICITS IN PERSONS WITH A SEMANTIC VARIANT OF A PRIMARY PROGRESSIVE APHASIA
}

\author{
Lana Jerkicl, Dragan Pavlovic', Mile Vukovic', Jelena Todorovic', Mirna Zelic ${ }^{2}$ \\ ${ }^{1}$ University in Belgrade, Faculty for Special Education and Rehabilitation, Belgrade, Serbia \\ ${ }_{2}^{2}$ Institute for Psychophysiological Disorders and Speech Pathology "Prof. dr Cvetko Brajovic", Belgrade, Serbia
}

\section{PROFIL JEZIČKIH I KOGNITIVNIH DEFICITA KOD OSOBA SA SEMANTIČKOM VARIJANTOM PRIMARNE PROGRESIVNE AFAZIJE}

\author{
Lana Jerkić1, Dragan Pavlović1, Mile Vuković1, Jelena Todorović1, Mirna Zelić2 \\ IUniverzitet u Beogradu, Fakultet za specijalnu edukaciju i rehabilitaciju, Beograd \\ ¿Zavod za psihofiziološke poremećaje i govornu patologiju „,Prof. dr Cvetko Brajović“, Beograd
}

\begin{abstract}
Primary progressive aphasia (PPA) includes a group of neurodegenerative disorders that are characterized by progressive deterioration of language functions, while other cognitive functions, at least at the onset of the disease, are relatively spared. There are three basic subtypes of PPA: the nonfluent progressive aphasia ( $n v P P A)$, the semantic variant of a primary progressive aphasia ( $S v P P A)$, and the logopenic progressive aphasia (lvPPA). The semantic variant of a PPA can also be found in the literature under the term of semantic dementia. It is clinically manifested by progressive deterioration of semantic knowledge, fluent aphasia, impaired naming and comprehension, prosopagnosia and surface dyslexia and dysgraphia (in languages with irregular orthography). As the disease progresses, other cognitive changes can be observed. The main cause of the disorder is progressive bilateral atrophy of the anterior temporal lobes, which is more manifested in the left hemisphere. The literature is modest in terms of the use of specific treatment methods in the rehabilitation of these patients. Since speech and language disorders are the most conspicuous symptom, at least at the beginning of the disease, the role of speech therapists in the assessment and restitution of speechlanguage and communication skills is also indisputable.
\end{abstract}

Key words: aphasia, primary progressive; frontotemporal dementia; language disorders

\section{INTRODUCTION}

Primary progressive aphasias (PPA) include a group of focal degenerations that involve areas of the cerebral cortex that are part of the speech area, which is usually in the left hemisphere in almost all right-handed people and over half of left-handed people (1). PPA is a manifestation of frontotemporal lobar degeneration (FTLD) and frontotemporal dementia (FTD) (2). These two similar terms designate specific clinical picture (FTD; behavioral variant and language variants) and clinico-pathological findings with characteristic molecular and hystological characteristics (FTLD). FTLD-related language disorders are divided into three groups: the nonfluent progressive

\section{SAŽETAK}

Primarna progresivna afazija (PPA) obuhvata grupu neurodegenerativnih poremećaja, koje karakteriše progresivno propadanje jezičkih funkcija, dok su druge kognitivne funkcije, barem na početku bolesti, relativno pošteđene. Izdvojene su tri osnovne varijante PPA: nefluentna progresivna afazija (nvPPA), semantička varijanta primarne progresivne afazije (svPPA) $i$ logopenična progresivna afazija (lvPPA). Semantička varijanta PPA može se pronaći u literaturi i pod nazivom semantička demencija. Klinički se ispoljava progresivnim propadanjem semantičkog znanja, fluentnom afazijom, oštećenim imenovanjem $i$ razumevanjem, prozopagnozijom $i$ površinskom disleksijom $i$ disgrafijom (u jezicima $s$ nepravilnom ortografijom). S progresijom bolesti, uočavaju se i druge promene na kognitivnom planu. Osnovni uzrok ove bolesti je progresivna obostrana atrofija prednjih temporalnih režnjeva, koja je izraženija u levoj hemisferi. Nema dovoljno podataka u literaturi o korišćenju specifičnih metoda tretmana u rehabilitaciji ovih bolesnika. S obzirom na to da su govorno-jezički poremećaji najupadljiviji simptom, bar na početku bolesti, nesporna je i uloga logopeda u proceni $i$ restituciji govorno-jezičkih $i$ komunikativnih sposobnosti.

Ključne reci: afazija, primarno progresivna; frontotemporalna demencija; poremećaji govora

aphasia (nfvPPA), the semantic variant of primary progressive aphasia (semantic dementia - svPPA), and the logopenic variant of progressive aphasia (lvPPA) (3).

PPA is an isolated disorder of language functions where global dementia occurs very late so these patients stay independent for a long time (4). The svPPA can also be found in the literature named semantic dementia (SD). It is manifested by insidious, progressive deterioration of language functions while other cognitive domains remain relatively preserved. As the disease progresses, patients show more and more pronounced deficits and difficulties in communication, which certainly contributes to the deterioration of everyday life activities (5). The criteria for the diagnosis of PPA were given by Mesulam (6). 
The disease begins in the presenile period, and the process usually lasts longer than 10 years. The most common is the non-fluent type of PPA (4). In the later stages of the disease, in all PPA subtypes, global aphasia occurs with mutism or, less frequently, with stereotyped speech (7).

This review paper aims to encroach contemporary information about the svPPA.

\section{SEMANTIC VARIANT OF PRIMARY PROGRESSIVE APHASIA}

The time of onset of SvPPA and duration of the disease is variable. It usually begins between the ages of 40 and 79 years, with an average of 60 years (8). Patients usually live seven to nine years after the onset of the first symptoms of the disease (9). The literature on epidemiological data on this type of svPPA is scarce. It is thought to account for about $20 \%$ of all FTLD cases (10), and according to other data they cover one-third of all FTD (11).

\section{PATHOLOGY}

Semantic dementia is the most frequent FTLD and it is associated with neuronal inclusions that contain the TAR DNA-binding protein 43 (TDP-43, transactive response DNA binding protein $43 \mathrm{kDa}$ ) (12). The biggest number of cases occur sporadically, and in an extremely small percentage of cases the genetic component is present (13) The results of magnetic resonance imaging (MRI) of brain show bilateral cortical atrophy of the anterior temporal lobes, which is more pronounced in the left hemisphere, especially in the ventral and lateral regions $(14,15)$ while a smaller percentage of cases are associated with the pathology of the right hemisphere (16). Changes were also found in the white matter pathways of the hemispheres (17).

Patients with right-hemispheric svPPA are more difficult to diagnose because initial behavioral disorders may be more pronounced than semantic disorders. Studies have shown that there are two variants. One is the mirror analogue of svPPA with disease spread occurring interhemispherically to the left temporal lobe (bilateral lesions), and another with behavioural symptoms where atrophy spreads intra-hemispherically, predominantly affecting the right frontal and parietal lobe $(16,18,19)$.

It has also been suggested that early bilateral hippocampal atrophy, predominantly on the left side, may be an early marker for the occurrence of svPPA (20). It has been observed that the anterior part of the hippocampus is included in the neural network for semantic memory, while the posterior part of the hippocampus is included in the network of episodic memory. The results of the study with functional MRI (fMRI) showed that there is a functional disconnection mainly of the left anterior hippocampus with the left angular gyrus, the left and right ventromedial frontal cortex, and the medial and superior temporal gyrus (21). Given the fact that these brain regions are included in the semantic memory network, these authors suggest that such a finding can be a potential substrate of semantic deficits.

\section{PROFILE OF SPEECH-LANGUAGE AND COMMUNICATION ABILITIES IN SVPPA}

One of the first symptoms of the disease is the loss of semantic knowledge. It is clinically manifested by fluent aphasia, with severe anomia, impaired comprehension of words, and associative visual agnosia (3).

In patients with svPPA, progressive decline in both receptive and expressive language functions may be observed. The most dominant symptom is impaired lexical semantics, which is manifested by difficulties in naming, understanding the meaning of words, and reduced achievement on tests of semantic verbal fluency (3). People with svPPA are usually unaware of their disorder although they complain of difficulty finding words (9). Concerning the modalities of language function, the manifestation of language deficits is reflected in the areas of spontaneous speech, nomination, comprehension, reading, and writing. The clinical picture of this form of PPA is similar to transcortical sensory aphasia (22).

The spontaneous speech of these patients is fluent, logorrheic, circumlocutionary, and saturated with semantic paraphasia. The grammatical and phonological structure of the language is preserved. Pauses in speech reflect difficulties in finding targeted words. Unlike other PPA subtypes, in which patients try to find the word they need (with variable success), patients with svPPA do not try to find an adequate lexical unit during the conversation (23).

Although naming disorders are present in all PPA subtypes, they are the most pronounced in svPPA, especially compared to other language modalities that are relatively spared (13). The nomination is damaged by the type of semantic anomia, with the loss of meaning of the word. Patients are often unable to connect two semantically related objects or words, as well as to select an object based on its function. Semantic paraphasias of a higher category are common (for example, instead of a cat, they say animals). Deficits of lexical-semantic abilities are more pronounced for low-frequent words as well as for nouns, so this manifestation of impairment is also called "loss of memory for names", i.e. they are unable to accurately express their thoughts $(3,7,24)$.

In terms of comprehension, progressive deterioration is observed and deficits are manifested already at the level of single-word comprehension (especially of words that 
are less frequently used), pictures, smells, tastes, and sounds (16). In the initial stages of the disease, sentence comprehension and everyday conversation are preserved. As the disease progresses, significant deficits manifest in the understanding of words denoting certain semantic categories, especially for animals, fruits, and vegetables (25). Articulation and prosody, as well as the repetition of single-words and sentences, are relatively intact (3), although some researchers point out that these individuals also show deficits in terms of sentence repetition (26).

In languages with irregular orthography symptoms of surface dyslexia and surface dysgraphia can be observed (16). With the progressive loss of meaning of the words, patients are unable to understand what they have read, and in written naming, the same deficits are manifested as in spontaneous speech (9).

At the macrolinguistic level, deficits manifest themselves in terms of discourse. The narrative discourse of these patients is usually described as "empty" (27). They omit semantically significant words, especially nouns, and replace them with pronouns. There are disturbances in maintaining the coherence of the discourse and the ability to maintain the theme of conversation decreases with disease progression $(3,28)$.

There are speech and language changes with fast speech and interruption of others, idiosyncratic use of words, absence of phonemic paraphasia, preserved calculia (4). There is also tinnitus, hyperacusis, as well as an aversion to certain sounds from the environment. These symptoms cannot be explained by the existence of peripheral hearing impairment and they are most likely of central origin. People from the environment, based on the patient's behavior, often conclude that they are deaf (23).

The assessment of language abilities in bilingual people showed that disorders of receptive and expressive language are present in both languages and that the impairment is more pronounced in a second language that is the non-mother tongue. The second language is thought to be more vulnerable when it comes to neurodegenerative impairments (29).

\section{PROFILE OF COGNITIVE FUNCTIONING IN SVPPA}

Despite the inevitable cognitive deterioration, some studies have proven the preserved cognitive domains in these patients. Nonverbal executive functions, attention, visuoconstructive functions, topographic and episodic memory, praxia, and computation are relatively spared $(30,31)$.

In the later stages of the disease, probably by engaging of the right temporal lobe and connection with the orbitofrontal cortex, behavioral disorders such as obsession, mental rigidity, narrowed interest, increased sensitivity to pain and temperature, when the left hemisphere is affected, may occur $(32,33)$. Disinhibition, impulsivity, bizarre food choices/hyperphagia, and repetitive and stereotyped behaviors may also occur (34). Behavioral manifestations may be due to hypometabolism in limbic regions, such as the amygdala, insula, or orbitofrontal cortex (30).

Due to behavioral disorders that may manifest with disease progression, these patients may look like the behavioral variant of FTD. The key diagnostic criterion for differentiating these two disorders is the presence of early prosopagnosia in right-sided svPPA due to the involvement of visual regions. Concerning the speech characteristics, short pauses for finding words are possible in patients with svPPA, in contrast to non-fluent speech with effort in nvPPA or speech with longer pauses in lvPPA. Also, verbal memory disorders are not characteristic of nvPPA, which may also serve in the differential diagnosis $(1,35)$.

Patients with svPPA have been shown to have difficulties recognizing emotions in visual and acoustic modalities as well as in tasks that require the integration of information from multiple modalities (36). They also show socio-emotional deficits that they are primary, and not a consequence of linguistic and other impairments. Such impairments are more pronounced in svPPA, compared to the other two subtypes of PPA (lpvPPA and nfvPPA). They also manifest impairment of the Theory of mind, as well as impairments of cognitive and affective empathy (36,37), associative agnosia in several modalities, and disorders of recognizing familiar faces (prosopagnosia) (24).

\section{HYPOTHESES ON THE ORIGIN OF SOME DEFICITS IN SVPPA}

Patterson et al. (38) tried to explain the nature and origin of semantic deficits that manifest in svPPA with the hypothesis of a "semantic loop". The semantic loop combines information from different sensory and motor areas to create an amodal semantic representation (39). Given that these patients show patterns of semantic decline in all modalities and all types of conceptual knowledge, the authors concluded that the anterior temporal lobes support the semantic loop (39).

The connectionist model of parallel distributed processing - PDP model (40) is also known. This model attempts to explain the origin of semantic deficits and their relationship, with the appearance of symptoms of surface dyslexia and dysgraphia in patients with svPPA. According to that model, semantic, phonological, and orthographic patterns are directly connected through "hidden layers/units", without any explicit application of lexical representation. The model argues that the 
processing of irregular words, especially low-frequency ones, necessarily depends on the reading/writing pathway that includes semantics, while real words can also be processed directly from orthographic to sound patterns. This path is also crucial for new or non-words that are exclusively processed directly. Proponents of this model claim that semantic impairments cause the appearance of surface dyslexia and dysgraphia and that the mental lexicon has no role in the occurrence because according to their view, it does not exist (41). Other authors claim that svPPA also affects the mental lexicon. These patients show not only semantic but also lexical impairments. Patients are significantly more unsuccessful in reading and writing irregular than regular words, which is also a feature of surface dyslexia and dysgraphia (42).

\section{ASSESSMENT AND DIAGNOSIS OF SVPPA}

The clinical assessment of PPAs usually involves taking additional information from people in the patient's environment about the duration and progression of symptoms, because they are usually the first to notice them. It is also important to take information about a person's premorbid language abilities such as formal education, occupation, presence of specific developmental disorders (stuttering or dyslexia), presence of visual or auditory deficits that may affect test performance. Neuropsychological testing involves the application of adequate tests in which different modalities of language functions and other cognitive functions are assessed (7). It is especially useful to examine confrontation naming with a clear frequency gradient from the impossibility of finding less frequent words and with an easier understanding of high-frequency words, at least at the onset of the disease (1).

The assessment of speech-language functions is a key aspect of diagnosis. It provides data that can be used in the differential diagnosis, serves to plan interventions, and monitor cognitive-linguistic status over time (43). The most commonly used tests are those that are designed to assess speech and language abilities in people with aphasia, such as the Boston Diagnostic Aphasia Examination (BDAE) and the Western Aphasia Battery (WAB) $(44,45)$. Specific tests have also been designed for the differential diagnosis and monitoring of disease progression in people with PPA, such as The Progressive Aphasia Severity Scale - PASS (46), The Progressive Aphasia Language Scale - PALS (47), Clinical Dementia Rating - CDR, etc. $(43,48)$.

Gorno-Tempini et al. (13) defined criteria at three levels according to which SvPPA can be diagnosed:

LEVEL I - The clinical diagnosis of svPPA is made based on characteristic speech and language disorders. Both of the following basic symptoms must be present:
1) impaired confrontation naming and impaired singleword comprehension;

2) three of the following symptoms: impaired knowledge of objects (particularly for low-frequency and low-familiarity objects); surface dyslexia or dysgraphia; spared repetition; preserved speech production (grammar and articulation);

LEVEL II - Imaged-supported diagnosis where structural and functional changes characteristic of this PPA subtype have been found. Both of the following criteria must be present:

1) a clinical diagnosis of svPPA;

2) the imaging must show one or more results:

a) predominant anterior temporal lobe atrophy and / or

b) predominant hypoperfusion or hypometabolism on SPECT or PET in the anterior temporal regions;

LEVEL III - svPPA with unambiguous pathology and implies an association with a known biological factor:

1) established clinical diagnosis (first criterion) or any of criteria 2 and 3 .

2) histopathological evidence of specific neurodegenerative pathology (eg FTLD-tau, FTLDTDP, AB, other);

3) presence of a known pathogenetic mutation;

\section{TREATMENT OF LANGUAGE DEFICITS IN SVPPA}

Despite the inevitable deterioration of semantic knowledge, some authors believe that spared neural circuits and cognitive mechanisms may support the restitution of the nomination. It is also considered possible to maintain this progress for several years after the onset of the disease, despite the inevitable deterioration of semantic knowledge (49). Treatment of anomia gives the best results in the earlier stages of the disease when there are memory reserves that can support learning. As comprehension disorders progress, restorative strategies become less effective (50).

The behavioral approach in the treatment of deficiency shows significant results in improving the targeted function of language, however, there are some limitations. The biggest disadvantage of this approach is the lack of generalization and long-term effects of treatment. Possible reasons include heterogeneity of symptoms and pathology that are reflected in different variants of PPA, different stages of disease progression on the initial basis, and other causes (51).

Rehabilitation of patients with semantic dementia is conditioned by context and there is no generalization of knowledge to objects and tasks that have not been treated $(52,53)$. Patients with more preserved semantic knowledge progress better in therapy. Several guidelines are given 
that can serve in the restitution of nomination in patients with svPPA, such as usage of known objects in therapy; the organization of objects into semantic categories can promote re-learning and retention; patient participation in the choice of facilities used in therapy may motivate patients in treatment; frequent repetition of familiar terms delays their forgetting, and generalization of what was learned during treatment gives better results, etc. (53). It is thought that providing a semantic cue to patients with SvPPA facilitates verbal learning and that the use of this strategy can generally improve learning capacities in these patients (54).

\section{CONCLUSION}

The semantic variant of primary progressive aphasia is one of the three possible variants of the manifestation of language disorder in FTLD. The anatomical correlate most commonly associated with SvPPA is bilateral cortical atrophy of the anterior temporal lobes, especially in the left hemisphere. In addition to changes in gray matter, some studies show that there are also impairments of white matter and subcortical structures in this neurodegenerative disease.

Patients with svPPA have predominantly language and cognitive deficits. The earliest symptom is the loss of semantic knowledge. The clinical picture is dominated by damage to lexical semantics, which is manifested by difficulties in naming, understanding the meaning of words, and reduced achievement on tests of semantic verbal fluency. Clinical assessment, neuropsychological testing, laboratory testing as well as the use of neuroimaging methods such as MR, PET, and SPECT play an important role in diagnosis.

A review of the literature concludes that there is little data regarding the use of specific treatment methods in this population. Since language disorders are the most conspicuous symptom of this disease, in addition to neuropsychological assessment and treatment, the role of speech therapists in assessing preserved language abilities as well as finding adequate treatment strategies in the rehabilitation of language functions is indisputable.

\section{REFERENCES}

1. Pavlović D, Pavlović A. Neuropsychology. From structure to brain function. Belgrade: Orion Art; 2018. (in Serbian).

2. Grossman M. Primary progressive aphasia: clinicopathological correlations. Nat Rev Neurol 2010; 6: 88-97.

3. Vuković M. Neurodegenerative speech and language disorders. Belgrade: University of Belgrade, Faculty of Special Education and Rehabilitation, 2019. (in Serbian).
4. Pavlović D, Pavlović A. Multiple cortical functions: neuropsychology and behavioral neurology. Belgrade: Orion Art, 2016. (in Serbian).

5. Vuković M. Primary progressive aphasia. Innovative approaches in speech therapy. Belgrade: Association of Speech Therapists of Serbia, 2017. (in Serbian).

6. Mesulam M. Primary progressive aphasia. Ann Neurol 2001; 49: 425-32.

7. Marshall C, Hardy C, Volkmer A, et al. Primary progressive aphasia: a clinical approach. J Neurol 2018; 265: 1474-90.

8. Hodges J, Mitchell J, Dawson K, et al. Semantic dementia: demography, familial factors and survival in a consecutive series of 100 cases. Brain 2009; 133: 300-6.

9. Harciarek M, Sitek E, Kertesz A. The patterns of progression in primary progressive aphasiaImplications for assessment and management. Aphasiology 2014; 28: 964-80.

10. Johnson J, Diehl J, Mendez M, et al. Frontotemporal lobar degeneration. Arch Neurol 2005; 62: 925-30.

11. Montembeault M, Brambati S, Gorno-Tempini M, Migliaccio R. Clinical, anatomical, and pathological features in the three variants of primary progressive aphasia: a review. Front Neurol 2018; 9: 626.

12. Rohrer JD, Geser F, Zhou J, et al. TDP-43 subtypes are associated with distinct atrophy patterns in frontotemporal dementia. Neurology 2010; 75: 2204-11.

13. Gorno-Tempini M, Hillis A, Weintraub S, et al. Classification of primary progressive aphasia and its variants. Neurology 2011; 76: 1006-14.

14. Collins J, Montal V, Hochberg D, et al. Focal temporal pole atrophy and network degeneration in semantic variant primary progressive aphasia. Brain 2016; 140: 457-71.

15. Gorno-Tempini M, Dronkers N, Rankin K, et al. Cognition and anatomy in three variants of primary progressive aphasia. Ann Neurol 2004; 55: 335-46.

16. Woollacott I, Rohrer J. The clinical spectrum of sporadic and familial forms of frontotemporal dementia. J Neurochem 2016; 138: 6-31.

17. Bouchard L, Wilson M, Laforce R, Duchesne S. White matter damage in the semantic variant of primary progressive aphasia. Can J Neurol Sci 2019; 46: 373-82.

18. Pavlović D. Frontotemporal dementia. Belgrade: Orion Art, 2019. (in Serbian).

19. Kamminga J, Kumfor F, Burrell J, Piguet O, Hodges J, Irish M. Differentiating between right-lateralised semantic dementia and behavioural-variant frontotemporal dementia: an examination of clinical characteristics and emotion processing. J Neurol Neurosurg Psychiatry 2014; 86: 1082-8. 
20. Chapleau M, Aldebert J, Montembeault M, Brambati S. Atrophy in Alzheimer's disease and semantic dementia: an ALE meta-analysis of voxel-based morphometry studies. J Alzheimers Dis 2016; 54: 94155.

21. Chapleau M, Montembeault M, Boukadi M, et al. The role of the hippocampus in the semantic variant of primary progressive aphasia: a resting state fcMRI study. Hippocampus 2019; 29: 1127-32.

22. Vuković M. Aphasiology. 4th ed. Belgrade: Association of Speech Therapists of Serbia, 2016. (in Serbian).

23. Volkmer A, Rogalski E, Henry M, et al. Speech and language therapy approaches to managing primary progressive aphasia. Pract Neurol 2020; 20: 154-61.

24. Pavlovic D. Dementia - diagnosis, therapy and care. Belgrade: Orion Art, 2012. (in Serbian).

25. Mesulam M, Rogalski E, Wieneke C, et al. Primary progressive aphasia and the evolving neurology of the language network. Nat Rev Neurol 2014; 10: 554-69.

26. Leyton C, Savage S, Irish M, et al. Verbal repetition in primary progressive aphasia and Alzheimer's disease. J Alzheimers Dis 2014; 41: 575-85.

27. Lima BS, Levine B, Graham NL, et al. Impaired coherence for semantic but not episodic autobiographical memory in semantic variant primary progressive aphasia. Cortex 2020; 123: 72-85.

28. Jarrold W, Peintener B, Wilkins D, Vergryi D, Richey C, Gorno-Tempini M. Aided diagnosis of dementia type through computer-based analysis of spontaneous speech. Baltimore: Association for Computational Linguistics, 2014.

29. Ellajosyula R, Narayanan J, Patterson K. Striking loss of second language in bilingual patients with semantic dementia. J Neurol 2020; 267: 551-60.

30. Iaccarino L, Crespi C, Della Rosa P, et al. The semantic variant of primary progressive aphasia: clinical and neuroimaging evidence in single subjects. PLOS One 2015; 10: e0120197.

31. Gordon E, Rohrer J, Kim L, et al. Measuring disease progression in frontotemporal lobar degeneration: a clinical and MRI study. Neurology 2010; 74: 666-73.

32. Fletcher P, Warren J. Semantic dementia: a specific network-opathy. J Mol Neurosci 2011; 45: 629-36.

33. Snowden J, Adams J, Harris J, et al. Distinct clinical and pathological phenotypes in frontotemporal dementia associated with MAPT, PGRN and C9orf72 mutations. Amyotroph Lateral Scler Frontotemporal Degener 2015; 16: 497-505.

34. Rosen H, Allison S, Ogar J, et al. Behavioral features in semantic dementia vs other forms of progressive aphasias. Neurology 2006; 67: 1752-6.
35. Joubert S, Felician O, Barbeau E, et al. The right temporal lobe variant of frontotemporal dementia. J Neurol 2006; 253: 1447-58.

36. Fittipaldi S, Ibanez A, Baez S, Manes F, Sedeno L, Garcia A. More than words: social cognition across variants of primary progressive aphasia. Neurosci Biobehav Rev 2019; 100: 263-84.

37. Bejanin A, Chételat G, Laisney M, et al. Distinct neural substrates of affective and cognitive theory of mind impairment in semantic dementia. Soc Neurosci 2016; 12: 287-302.

38. Patterson K, Nestor P, Rogers T. Where do you know what you know? The representation of semantic knowledge in the human brain. Nat Rev Neurosci 2007; 8: 976-87.

39. Visser M, Jefferies E, Lambon Ralph MA. Semantic processing in the anterior temporal lobes: a metaanalysis of the functional neuroimaging literature. $\mathrm{J}$ Cogn Neurosci 2010; 22: 1083-94.

40. McClelland J, Rogers T. The parallel distributed processing approach to semantic cognition. Nat Rev Neurosci 2003; 4: 310-22.

41. Plaut D, McClelland J, Seidenberg M, Patterson K. Understanding normal and impaired word reading: computational principles in quasi-regular domains. Psychol Rev 1996; 103: 56-115.

42. Teichmann M, Sanches C, Moreau J, et al. Does surface dyslexia/dysgraphia relate to semantic deficits in the semantic variant of primary progressive aphasia? Neuropsychologia 2019; 135: 107241.

43. Grasso S, Henry M. Assessment of individuals with primary progressive aphasia. Semin Speech Lang 2018; 39: 231-41.

44. Goodglass H, Kaplan E, Barresi B. BDAE-3: Boston Diagnostic Aphasia Examination. $3^{\text {rd }}$ ed. Philadelphia: Lippincott Williams \& Wilkins, 2001.

45. Kertesz A, Raven JC; PsychCorp. WAB-R: Western Aphasia Battery-Revised. San Antonio: PsychCorp, 2007.

46. Sapolsky D, Domoto-Reilly K, Dickerson B. Use of the Progressive Aphasia Severity Scale (PASS) in monitoring speech and language status in PPA. Aphasiology 2014; 28: 993-1003.

47. Leyton C, Villemagne V, Savage S, et al. Subtypes of progressive aphasia: application of the international consensus criteria and validation using $\beta$-amyloid imaging. Brain 2011; 134: 3030-43.

48. Morris J. The Clinical Dementia Rating (CDR): Current version and scoring rules. Neurology 1993; 43: 2412-4. 
49. Graham KS, Patterson K, Pratt KH, Hodges JR. Can repeated exposure to" forgotten" vocabulary help alleviate word-finding difficulties in semantic dementia? An illustrative case study. Neuropsychol Rehabil 2001; 11: 429-54.

50. Henry M, Beeson P, Rapcsak S. Treatment for anomia in semantic dementia. Semin Speech Lang 2008; 29: 60-70.

51. Tippett DC, Hillis AE, Tsapkini K. Treatment of Primary Progressive Aphasia. Curr Treat Options Neurol 2015; 17: 362.
52. Bier N, Macoir J, Gagnon L, Van der Linden M, Louveaux S, Desrosiers J. Known, lost, and recovered: efficacy of formal $\square$ semantic therapy and spaced retrieval method in a case of semantic dementia. Aphasiology 2009; 23: 210-35.

53. Jokel R, Graham N, Rochon E, Leonard C. Word retrieval therapies in primary progressive aphasia. Aphasiology 2014; 28: 1038-68.

54. Milano N, Williamson J, Heilman K. Improved verbal learning in the semantic variant of primary progressive aphasia when using semantic cues. Neurocase 2014; 21: 345-50. 